\title{
Body, culture and meaning
}

Open acess

${ }^{1}$ Master's Degree in Collective Health from the Federal University of Espírito Santo / UFES. She is an Assistant professor of the School of Sciences of Santa Casa de Misericórdia de Vitória (EMESCAM). Vitoria - ES, Brazil.

${ }^{2} \mathrm{PhD}$ in Nursing from the University of São Paulo and is an Associate Professor at the Federal University of São Paulo, in the Paulista School of Nursing - EPE / UNIFESP. São Paulo - SP, Brazil.

${ }^{3} \mathrm{PhD}$ in Nursing from the Federal University of São Paulo, and is a Professor at the Federal University of São Paulo, also Director of the Paulista Nursing School - EPE / UNIFESP. São Paulo - SP, Brazil.

${ }^{4}$ Master's Degree in Health Sciences from the Federal University of São Paulo, in the Paulista School of Nursing - EPE / UNIFESP. São Paulo - SP, Brazil.

Corresponding author: claudias_dourado@hotmail.com Manuscript received: November 2017 Manuscript accepted: January 2018 Version of record online: June 2018

\author{
Cláudia de Souza Dourado', Suzete Maria Fustinoni², Janine \\ Schirmer ${ }^{3}$, Camila Brandão-Souza ${ }^{4}$
}

\begin{abstract}
Introduction: Human beings go through history in search of the plenitude and perfection of the human body. The actors have changed and the scene has changed, and likewise the sociocultural context, the tastes and interpretations, and the meaning have changed, yet the search for the ideal body remains.
\end{abstract}

Objective: A critical-reflexive approach is proposed regarding the standard of the body throughout the historical trajectory, as well as its cultural representativeness and the meaning attributed to it.

Methods: This is a critical-reflexive dissertation based on existing literature. We have used the: MEDLINE, LILACS, Scientific Electronic Library - SciELO and Bireme databases; as well as Google Scholar and grey literature. The preparation of the manuscript followed the norms of literature reviews, and nearly attained the qualitative approach.

Results: One must consider the relationship that the media establishes with the body, impelling a relentless search for a standardized reflection in the mirror, seen as beauty; the culture of purchasing power regarding the female body, of discrimination, of violence, and of indifference. It reveals a discussion of aspects that are important and fundamental to understand the body in its totality, not only as an organic structure, but also as something complex and subjective that suffers constant influences from the environment to which it is exposed and from the time and society in which it is inserted.

Conclusion: It may be concluded that the body has always been in a prominent position in the civilizations of the numerous historical periods mankind has lived through, and regardless of when, there has always been a corporal stereotype to be followed, cultivated and worshiped, and the search for this conquest continues in current days.

Keywords: human body, culture, beauty industry, narcissism. 


\section{INTRODUCTION}

The human body is allomorphic, it is adaptive and adapted ... it is held responsible, it is looked at, it is the object of criticism and desire, of rules and repressions ... what is not always remembered is that along with a body, there is always a human. The human body, its various forms, contours, colors and meanings are attributed within a sociocultural context which crosses history, constantly seeking for tangible and unattainable perfection.

Its meaning has undergone many changes over time, it has symbolized purity, desire, chastity, fertility, lust, freedom, ostentation, economic status, consumerism, narcissism, and health, and it always carries a relationship

\section{METHODS}

This is a critical-reflexive study based on existing literature about the body and its meaning. We used the: MEDLINE, LILACS, Scientific Electronic Library SciELO and Bireme databases; as well as Google Scholar and grey literature, such as historians' blogs, periodicals, and magazine archives.

The theoretical construction of this article is based on bibliographic research, categorization of the subjects,

\section{RESULTS}

The human body is work force, machinery of existence, executor and provider. Well before meaning only status, the body had already been the abode of the spirit, and in some cultures it still is. In all the trajectory of its existence it was and is misunderstood within its limits, its singularity, its individuality, its beauty, and it's meaning.

But after all, what is beauty? It depends. Bodies with a minimum percentage of fat, hypertrophied muscles, well defined abdomens, rounded and firm breasts and buttocks, atrophied brains ... wrinkles from the sun of those who have the duty of being breadwinners, hanging breasts of those who provided a lot of breast milk, the scar of one who made birth possible, wisdom in the look ... Beauty depends on the evolutionary state of the beholder.

Just the same, as it is so relative, the beauty of bodies has always had an established pattern in every age. In ancient Greece the Greek man who was muscular and wealthy was the possessor of beauty and admiration through naked sculptures, whereas no beauty was attributed to women, to the contrary, feminine beauty was synonymous with perversity and a curse. This idolatry of the masculine body was also experienced in the Roman world, and at that time cosmetics played an important role for women, being condemned in medieval times through abomination by the Catholic Church, which attributed female beauty to the virtues of character and discretion ${ }^{1}$.

From the end of the Middle Ages until the present time the standard has been "From slender to plump and from natural to painted, the female silhouette and face has corresponded to the different conditions of diet, status and wealth, giving rise to new standards of appearance, and taste", largely based on criteria established by the men of the time ${ }^{2}$. of reciprocity with society, as well as having the power to influence it.

By mankind dedicating it to understanding this complex subject, concerns arose and took on significant proportions. What is the meaning of the body, its history, and its culture? Why has the body now been reduced to an image? What is the role of the media in this process? Does the body have a price? These questions have answers and interpretations, but rather than presenting them, it was sought to stimulate reflection about the body, not as a structure and an apparent coating, but with the complexity that it deserves and the subjectivity that it carries.

and interpretation and analysis of the findings, resembling a qualitative approach, because when there was saturation of speech, that is, the materials available did not bring out any novelties, the search was finalized. The preparation of the manuscript followed the norms of literature reviews, bringing out existing information, added to the critical analysis of the authors.

In the Renaissance, unlike the middle Ages, beauty was a visible reflection of an interior full of goodness, which should be exteriorized. The Italian renaissance influenced all Europe (16th century), extolling the naked, a plumper nude with large breasts, superior hips ${ }^{3}$, light skin and hair, and an oval face ${ }^{1}$.

Between the sixteenth and seventeenth centuries the palate was predominantly linked to foods derived from milk and sweets, characterizing European cuisine, which were understood as symbols of abundance, wealth, nobility and health, and as a result, fat bodies. Thus thinness became a sign of poverty and the absence of health and beauty ${ }^{3}$.

A century later the concept of fat began to change, along with feminine aesthetics, which assume delicacy and grace, translated by an image of tall, thin women, and this prevailed in the nineteenth century ${ }^{2}$.

In the twentieth century there was a movement in favor of the demystification of the figure of the body and of modesty. In the United States, between the 1950s and 1960 s, surgical interventions focused only on aesthetics, and there was a concern with longevity and with the eternalization of beauty ${ }^{4}$.

In Brazil the bikini arose, as well as the "pregnant belly in a bikini on the beach of Ipanema" eternalized by Leila Diniz, incarnating the spirit of the city, in which lean, muscular, tall, tan bodies lived in harmony with stretch marks and cellulitis of other bodies, with protruding and faded tummies, and then the Carioca body emerged ${ }^{5}$, a kind of genetic and cultural diversity that resulted in samba.

Dietary habits, hygiene and physical culture marked the second half of the 60s, staying good looking was necessary, vigor and youth were accessible in 
cosmetics shops, aging was no longer a virtue ${ }^{6}$. The bodies of sex symbols were eternalized in magazines, and the lean, white, middle-class standard superseded the plump, black, and poor bodies ${ }^{7}$. In the United States of the 1970s, campaigns that stimulated physical exercise and weight loss sought to reduce the morbidity and mortality resulting from changes in the cardiovascular system, and as a way to combat obesity, in the 1980 s the first fitness concepts ${ }^{8}$ arrived in Brazil, and as a consequence, the ex-fat people who had traded their fat for a "completely healthy" life in motion appeared.

The beautiful, natural body of the $60 \mathrm{~s}$ was transformed into the muscular one in the 80 s and came into the new millennium associating fitness with well-being. It is more than obvious that there is a much wider variety of contemporary body shapes and structures. "But magazines do not seem to know this, nor do they want to see it, nor do they have any industrial, commercial, or technological conditions or interests to show this variety".

Going far beyond aesthetics, the body carries the self, its experiences, meaning, rites and tradition. For Christians, the body is the temple in which the Holy Spirit dwells, yet in other beliefs it may be the instrument used for the incorporation of spirits who need to communicate, or those who are lost in deep sadness, or it is even a place that the soul.

In some African, Arab, Asian, American and even European countries, the interpretation of the body, or parts of it, differs from much of the world to the point of generating some discomfort with old (prehistoric) cultural practices and mobilizing human rights defense groups. An example of this is female circumcision (mutilation - this being the most controversial issue), as well as dry sex, transactional and intergenerational sex, and in all cases, beliefs and culture about the female body. For the female body maternity is the purpose, and female organs are seen as the means of production and consumption, whereas for an inexperienced man who has few sexual relations, the ideal feminine identity is virginity ${ }^{10}$.

Female circumcision has levels from 1 to 4 , with level 1 being only the removal of the clitoris, its glans and its suspensory ligament; while level 2 requires the removal of the labia minora along with the clitoris and glans; level 3 is called pharaonic because it has been performed since the times of the pharaohs, and it requires the removal of the clitoris and glans, the labia minora, and the medial portion of the labia majora, and there is still the possibility of suturing the remaining parts of the labia majora to create a smooth surface, with only a small hole for urination and menstruation, or infibulation. Level 4 is difficult to fit into most World Health Organization definitions as it requires a number of cutting patterns, including the joining together of aspects of all previous levels, scraping the vaginal orifice, and introducing substances that cause narrowing of the vaginal canal, or lengthening the lips and clitoris $^{11}$. It is a rite that requires some financial resources and, therefore, whether or not it is performed also reflects the financial situation of the family ${ }^{12}$, being a symbol of status, nobility, chastity and purity.

One tends to think that all women are or were forced to go through the rite, but oddly enough, the practice was so significant for the girls themselves that when the Kenyan government (only one of the countries adept at the practice, among so many) prohibited the procedure from 1920 to 1930, the girls went into the jungle to be circumcised13. But in fact, many women think differently nowadays and refuse to have the procedure performed, or if they have already had it done, they flee with their daughters in search of refuge and asylum, so that their children do not have to go through the same experience.

Mistaken beliefs extend the tradition. It is believed that the clitoris grows to the point that it resembles the male sexual organ, being extremely toxic to gestation and birth, and bringing a curse upon the fetus ${ }^{14}$.

Dry sex is a form of respect for one's spouse. The body fluids that the female body receives and produces are powerful and linked to fertility, but if they are misused they are dangerous. In the excitement at the time of intercourse, women who become very lubricated are compared to sex workers, so lubrication is attributed to impurity, promiscuity and its absence means youth, purity, and chastity ${ }^{10}$.

Intergenerational sex and transactional sex are socially accepted and defended cultural practices in Tanzania. The first concerns the involvement of younger women with older and wealthier men, using the body as a way of supporting the family, and the latter is about the body being used as trade currency, but it differs significantly from prostitution, since there is a selection of partners and concern with what is "morally" accepted ${ }^{15}$.

A study in Tanzania found that most young women believed that the body could be a kind of commodity and they would exchange it for money. Men reinforced the belief, stating that a woman's body is like the meat in a butcher's shop, that is, it is on display and for sale, so it is merchandise that should not be given away but purchased; which is an easy way to get sex, and since it is paid for it should not be turned down. Most of the men who were interviewed defended the culture, stating that nothing should change since the women would not accept intercourse without the exchange by forcing them to perform non-consensual sex. The practice even had support from parents as the mothers argued that only foolish girls had sex with nothing in return, and they ended up as a subject of gossip and contempt of men ${ }^{15}$.

In several other cultures, the body is the right of the one who possesses it, and sex is experienced with love, horniness or desire, or at least of course with consent. Intimacy is great, and should not be invaded, violated or forced. Several women daily try to (re)find the meaning of the body and sex after an episode of sexual violence. Emotional marks are stored in the body, in attitudes, behaviors, reactions, and corporeity ${ }^{16}$. Sometimes a woman is silent for fear of judgment, shame, humiliation or guilt ${ }^{17,18}$, developing syndromes, phobias, panic and depression ${ }^{18}$. Overcoming all this may occur when the victim can see beyond what has happened, deciding to go on and no longer consider herself a victim, but rather a survivor $^{19}$, a kind of change of viewpoint, confrontation, and resistance.

And what about when violence comes about through discrimination, prejudice and veiled (or not really 
so veiled) non-acceptance? How can we understand it when a human does not see him- or her-self in the body that nature has determined? "Transsexuality is a matter of identity. It is not a mental illness, it is not a sexual perversion, nor is it a debilitating or contagious disease", and contrary to what one imagines, it is not about sexual orientation. It is a condition rather than a blessing or a curse. For transsexuals, their bodies do not follow their thoughts and the way in which they see themselves, necessitating adjustment so that the mind and body can go together ${ }^{20}$. It is worrisome that another person's identity bothers and upsets so many conservatives who, out of ignorance, discriminate and believe that this condition is unacceptable. It is unacceptable that the transsexual is bound to live in a body that does not represent him and which does not translate his soul. In reality, this condition, if not addressed and worked on, can cause a human being to destroy himself gradually, making his life unfeasible and "unlivable ${ }^{21}$. A study of transsexuals reported intense psychic suffering, which was translated into depression, suicide attempts, distress, eating disorders, not only by biological conflict, but also by social consequences of this condition $^{21}$.

There are innumerous barriers to accepting one's body, including some that are maintained and underpinned by the very insecurity and psychological vulnerability of the affected person. Post-intervention body changes in the diagnosis of a disease that brings about modifications to the aesthetics and functionality of the body, especially those associated with some kind of mutilation or disfigurement, translate into direct implications in the person's life and affective ties.

Cancer is one of the most feared diseases and one that causes changes bodily image the most. The progression of the disease, as well as the treatment performed, can lead to devastating and often irreversible transformations. When faced with losses of certain parts of the body, such as with alopecia and swelling caused by chemotherapy, the subject no longer recognizes him- or her-self and starts to feel horrified, not accepting the bodily image ${ }^{22}$.

Considering that the breast is an important symbol of femininity, breast cancer is among the greatest of fears. The anguish of mutilation, the fear of dying, and the fear of losing partners as a consequence of the commitment of sexuality are experienced ${ }^{23}$, and these are impacts that reflect on women's self-esteem, self-image and selfconcept ${ }^{24}$. Nevertheless, for men the penis represents virility and the essence of masculinity. When the man with penile cancer finds himself facing a treatment such as penectomy, such a mutilating surgery, he no longer recognizes himself as a man, experiencing a great narcissistic wound and great losses in self-esteem ${ }^{25}$. In both cases there is a need for corporal and even cultural resignification.

In contemporary society, in which the worship of the body is so practiced and the search for perfection seems incessant, living with the eyes of others when it is not feasible to attain this ideal of beauty becomes a suffering experience for many. This suffering is intensified when these standards are displayed at all times by the media as being achievable, affordable and healthy, which has turned bodies into true laboratories in an attempt to achieve complete well-being.

The media makes use of strategies that are studied, intense, repetitive and manipulative to achieve their goal, which is almost always to encourage consumption, whether of goods, food, clothing, or a lifestyle... At all times it is possible to see the association of the standard of corporal perfection with some type of advertising in magazines, on television channels or over the internet. People become slaves and followers, submitting themselves to the rigorous and merciless discipline of the body industry.

The seduction provoked by the media generates ever greater desires in the pursuit of perfection. The world of advertising is not anything new; however, it was in the last century that the media gained force, becoming a dictator of fads. In the epoch of patriarchy, symbolic violence was exercised through the church, school and family, and even today it has been practiced, particularly on media platforms especially after the advent of the internet. The media play an essential role in the construction of the social imagination about the body.

The social symbols of the body and its being in good shape show themselves as factors that stimulate "self-esteem" and pass on the idea that they are related to the willpower of the individual, suggesting that everyone can have the body that he or she wants, and it is enough just to want it ${ }^{9}$.

Social networks also constitute influential tools that intensify the imposition of this pattern even more, as they are connected to this process of propulsion to the pursuit of the perfect body ${ }^{26}$. Upon using them the individual incessantly seeks the greatest possible amount of reactions, such as "likes", "smiles", and compliments... Facebook, Instagram, Snapchat, and countless already networks that are extinct have propagated and do propagate personal fulfillment in exhibition. Access to tools that transform real photos into manipulated, "photoshopped" photos and the possibility of utilizing filters to make the images more attractive are translated from a lifestyle based on the worship of the body and consequently an illusory, unshakable happiness, at least on the screen. It is no longer enough how the individual sees himself, but rather how his image is being evaluated and judged by the virtual world ${ }^{26}$.

Everything has its price. But how much does a body cost anyway? How much does "the" body cost? The body is worth however much it consumes, simple as that. The aesthetics industry is growing in a frightening way. There are packages for cellulitis, stretch marks, and collective purchases to remove the blood vessels, wrinkles, as well as consortiums for larger goods, such as silicone, liposuction... and if money permits it, you can do everything on the same day, and even better, "without any danger".

People have not become uglier, or less beautiful; they have not become imperfect, or less perfect. The fact is they are constantly dissatisfied, and there is a reason for this: Happy, determined, satisfied people have other ambitions that go beyond consumption and the pursuit of perfection ... And that is a danger to the market.

The business of the body is intended to make 
it increasingly molded into a standard which is so unattainable that even the most beautiful of humans may feel troubled by not being like the established standards. The important issue is large-scale production, established molds and models that overshadow the beauty of singularity, individuality, and the individual ... not everyone can see this, in fact, the origin of the success of departmental bodies is blindness caused by marketing, the internet, and idleness.

It is believed that this dictated beauty is synonymous with health, joviality, youthfulness, willingness, and ideal cholesterol, triglyceride and glucose rates. No, it is not. At times this excess in holding oneself responsible, chronic dissatisfaction, revolt and constant diets leads to eating and image disorders (anorexia, bulimia), psychopathic disorders (melancholy, anxiety, depression), isolation and mood changes ${ }^{27,28}$. Making the body suitable to the induced model is not a recipe for satisfaction, although this achievement may occur, and it is often accompanied by an existential emptiness and a loss of spontaneity, naturalness and eroticism ${ }^{28}$.

The frenzied quest for the perfect body has been transforming gyms and academies into large mills of bodies, where the primary objective is no longer a healthy lifestyle, but rather the achievement of good shape and thinness, thus permitting a good presentation of the body to others5. There is a great dichotomy within these establishments, and the culture of the body is not the culture of health, as which they try to sell it.

Idolatry of the body has led many to ruin their own bodies. Health... health is but a detail. Lots of water to hydrate oneself and natural foods for an energy supply would be a good combination for exercise and healthy living. However, hyper-protein supplements and anabolic agents (steroids) have played a role in the "health space", the latter being even more worrisome, since they can present side effects of the mildest forms, such as acne and stretch marks, to the most serious ones, such as decreased myocardial function, liver damage and an increased risk of tumors ${ }^{29}$.

Building an athletic body or one with perfect curves, regardless of the effort and sacrifice involved, is part of a process of idealizing a self-image that is itself healthy, young, attractive and seductive ${ }^{30}$. This distortion

\section{CONCLUSION}

In this way the body, which is representative of the subject, is deeply persuaded by cultural and historical parameters, and it acquires meaning upon interacting with the surrounding environment, everything that surrounds it is impregnated with values, and thus, through this mutual relation, the human being manifests its socio-cultural dimension.

\section{REFERENCES}

1. Domingues JE. Ensinar história. [cited 2017 Sep 02] Available from: http://www.ensinarhistoriajoelza. com.br/a-beleza-na-grecia-antiga-e-hoje/.

2. Grieco S. O corpo, aparência e sexualidade. In: Duby G, Perrot M. História das mulheres no ocidente 3: do renascimento à idade moderna (71-120). Porto: Afrontamento, 1991; p.71-119.

3. Vasconcelos NA, Sudo I, Sudo N. Um peso na alma: o corpo gordo e a mídia. Rev Mal-Estar Subj. 2004;4(1):65-93. of the real sense of attending a gym imposes important re-significance of the body in the culture and it imprisons the individual in a constant process of frustration as not everything that one desire is possible to be achieved. A space that should represent health and physical well-being has today been invaded by easy methods to achieve the desirable standard body, but it seems to be too high a price to pay for perfection.

Besides having a perfect body, it is necessary that the body is young ... or at least, that it seems to be of a person younger than it really is, that is, one who is "conserved". We are not talking about active aging, with preserved functional capacities, or autonomy rather than fragility ... the order boils down to the image of the body.

The alterations of the connective tissue, which is part of the structure of the epidermis, dictates external changes, these modifications of the collagen-elastic apparatus throughout life history that justify many biomechanical and biochemical changes and adaptations of the skin due to aging ${ }^{31}$.

Maturity brings about white hair, flaccidity and other signs that "must" be combated with energetic body maintenance, using all the resources made possible by the beauty industry 9 . The concern here is not with the finitude of being, the closure of the cycle, or the fear of death. There is no problem with dying, as death is just a certainty; the problem lies in aging, or rather, the aging of the body.

In reality, old age is the privileged stage of narcissistic disillusion, old age has a time, a status, facets and prejudice in everything that is involved in $i^{32}$. It is necessary to understand that all bodies are transient, and that aging is often a great moment for reflection, because it is the moment when important things really gain importance ... Scars tell stories, wrinkles increase in smiles, but even so you want to smile ... It is understood that a lot of time has been lost with worries that did not make the least bit of sense, more time is desired ... The reverence and the cult of the physical being for many loses its sense, as it is but a stage of evolution, real sense is now about living intensely. Youth was the rehearsal, the stage is now filled by another actor, the scene continues, and it is much more interesting, to be sure.

In this context, it is fundamental to assimilate the body holistically, not being limited to its biological aspect in itself, but all its subjectivity is expressed by feeling, thinking and acting, aspects that really characterize it as being endowed with humanity. 
4. Prado Filho K, Trisotto S. O corpo problematizado de uma perspectiva historico-política. Psicol Estud. 2008;13(1):115-21. DOI: http://dx.doi.org/10.1590/S1413-73722008000100014

5. Goldenberg M. Nu \& vestido: dez antropólogos revelam a cultura. $2^{\mathrm{a}}$ edição. Rio de Janeiro: Record; 2007.

6. Prost A. Fronteiras e espaços do privado. In: Prost A, Vincent G. História da vida privada da primeira guerra a nossos dias. V. 5. São Paulo: Companhia das letras, 1987; p.13-154.

7. Higonnet A. Mulheres, imagens e representações. In: Duby G, Perrot M. História das mulheres no ocidente 5: o século XX. Porto: Afrontamento, 1991; p.403-34.

8. Luz MT. Novos saberes e práticas em saúde coletiva: estudo sobre racionalidades médicas e atividades corporais. $3^{\mathrm{a}}$ edição. São Paulo: Hucitec; 2003.

9. Siqueira $D$, Faria $A$. Corpo, saúde e beleza: representações sociais nas revistas femininas. Comunic Mídia Consumo. 2007;4(9):171-88. DOI: http://dx.doi.org/10.18568/cmc.v3i9.95

10. Hilber AM, Kenter E, Redmond S, Merten S, Bagnol B, Low N, et al. Vaginal practices as women's agency in Sub-Saharan Africa: A synthesis of meaning and motivation through meta-ethnography. Soc Sci Med. 2012;74(9):1311-23. DOI: https://doi.org/10.1016/j.socscimed.2011.11.032

11. World Health Organization (WHO). Female genital mutilation: an overview. Geneva: WHO, 1998.

12. Shell-Duncan B, Hernlund Y. Female "circumcision" in Africa: culture, controversy and change. London: Lynne Rienner; 2000.

13. Einstein $\mathrm{G}$. From body to brain: considering the neurobiological effects of female genital cutting. Perspect Biol Med. 2008;51(1):84-97. DOI: https://dx.doi.org/10.1353/pbm.2008.0012

14. Abusharaf RM. Virtuous cuts: Female genital mutilation in an African ontology. J Fem Cult Stud. 2001;12(1):112-40.

15. Wamoyi J, Fenwick A, Urassa M, Zaba B, Stones W. "Women's bodies are shops": beliefs about transactional sex and implications for understanding gender power and HIV prevention in Tanzania. Arch Sex Behav. 2011;40(1):5-15. DOI: https://dx.doi.org/10.1007/s10508-010-9646-8

16. Labronici LM, Fegadoli D, Correa ME. The meaning of sexual abuse in the manifestation of corporeity: a phenomenological study. Rev Esc Enferm USP. 2010;44(2):401-6. DOI: http://dx.doi.org/10.1590/S0080-62342010000200023

17. Villela WV, Lago T. Conquistas e desafios no atendimento das mulheres que sofreram violência sexual. Cad Saúde Pública. 2007;23(2):471-5. DOI: http://dx.doi.org/10.1590/S0102-311X2007000200025

18. Mattar R, Abrahão AR, Andalaft NJ, Colas OR, Schroeder I, Machado SJR, et al. Assistência multiprofissional à vítima de violência sexual: a experiência da Universidade Federal de São Paulo. Cad Saúde Pública. 2007;23(2):459-64. DOI: http://dx.doi.org/10.1590/S0102-311X2007000200023

19. Duma SE, Mekwa JN, Denny LD. Women's journey of recovery from sexual assault trauma: a grounded theory -part 2. Curationis. 2007;30(4):12-20.

20. Jesus JG. Orientações sobre a população transgênero: conceitos e termos. Brasília: 2012.

21. Arán M, Zaidhaft S, Murta D. Transexualidade: corpo, subjetividade e saúde coletiva. Psicol Soc. 2008;20(1):70-9. DOI: http://dx.doi.org/10.1590/S0102-71822008000100008

22. Ferreira DM, Castro-Arantes JM. Câncer e corpo: uma leitura a partir da psicanálise. Analytica. 2014;3(5):37-71.

23. Rocha IMG, Almeida PCT, Ribeiro JFS. Seios, anseios e perdas: o corpo feminino e o câncer de mama como alvo de investimentos subjetivos. Rev Mosaico. 2013;4(1):5-10. DOI: https://dx.doi.org/10.21727/rm.v4i1.160

24. Silva CMC, Vargens OMC. A mulher que vivencia as cirurgias ginecológicas: enfrentando as mudanças impostas pelas cirurgias. Rev Latino-Am Enfermagem. 2016; 24:e2780. DOI: https://dx.doi.org/10.1590/1518-8345.1081.2780

25. Barros EN, Melo MCB. Câncer de pênis: perfil sócio-demográfico e respostas emocionais à penectomia em pacientes atendidos no Serviço de Psicologia do Hospital de Câncer de Pernambuco. Rev SBPH. 2009;12(1):99-111.

26. Lacerda I. A cultura do efêmero: o formato Snapchat nas redes sociais, a vontade de exposição e a construção da imagem individual. Intercom: Soc Bras Estudos Interdisciplinares da Comunicação: Anais do XXII Congresso de Ciências da Comunicação na Região Sudeste. Volta Redonda: 2017.

27. Kellner D. A cultura da mídia: estudos culturais: identidade e política entre o moderno e o pós-moderno. Bauru: EDUSC, 2001.

28. Boris GDJB, Cesídio MH. Mulher, corpo e subjetividade: uma análise desde o patriarcado à contemporaneidade. Rev Mal-Estar Subj. 2007;7(2):451-78. 
29. Hoffhman JR, Ratamess NA. Medical issues associated with anabolic steroid use: are they exaggerated? J Sports Sci Med. 2006;5(2):182-93.

30. Hansen R, Vaz AF. Treino, culto e embelezamento do corpo: um estudo em academias de ginástica e musculação. Rev Bras Cienc Esporte. 2004;26(1):135-52.

31. 31. Kono T, Tanii T, Furukawa M, Mizuno N, Kitajima J, Ishii M, et al. Correlation between ageing and collagen gel contractility of human fibroblasts. Acta Derm Venereol. 1990;70(3): 241-4.

32. Vilhena J, Novaes JV, Rosa CM. A sombra de um corpo que se anuncia: corpo, imagem e envelhecimento. Rev Latinoam Psicopatol Fundam. 2014;17(2):251-64. DOI: http://dx.doi.org/10.1590/1984-0381v17n2a08

\section{Resumo}

Introdução: O ser humano perpassa a história na procura da plenitude e da perfeição do corpo. Mudamse os atores, muda-se o cenário, o contexto sociocultural, os gostos e interpretações, o significado, e permanece-se a busca pelo corpo ideal.

Objetivo: Propõe-se uma abordagem de caráter crítico-reflexiva sobre o padrão do corpo ao longo da trajetória histórica, assim como sua representatividade cultural e o significado a ele atribuído.

Método: Trata-se de uma dissertação crítico-reflexiva construída com base em literatura existente. Utilizou-se os bancos de dados: MEDLINE, LILACS, Scientific Eletronic Library - SciELO e Bireme; bem como o Google Acadêmico e literaturas cinzentas. A elaboração do manuscrito seguiu as normas da revisão de literatura, e aproximou-se da abordagem qualitativa.

Resultados: Há de se considerar a relação que a mídia estabelece com o corpo, impulsionando uma busca incansável por um reflexo padronizado no espelho, encarado como beleza; A cultura do poder de compra sobre o corpo feminino, da discriminação, da violência, da indiferença. Revela-se uma discussão sobre aspectos fundamentais e importantes para se compreender o corpo na totalidade, não apenas como uma estrutura orgânica, mas como algo complexo e subjetivo que sofre constantes influências do ambiente ao qual é exposto, da época e da sociedade na qual está inserido.

Conclusão: Conclui-se que o corpo sempre esteve em uma posição de destaque nas civilizações dentre os inúmeros períodos históricos vividos, independente de qual momento, sempre houve um estereótipo corporal a ser seguido, cultuado e adorado, e a busca por essa conquista continua nos dias atuais.

Palavras-chave: corpo humano, cultura, indústria da beleza, narcisismo.

${ }^{\odot}$ The authors (2018), this article is distributed under the terms of the Creative Commons Attribution 4.0 International License (http://creativecommons.org/licenses/by/4.0/), which permits unrestricted use, distribution, and reproduction in any medium, provided you give appropriate credit to the original author(s) and the source, provide a link to the Creative Commons license, and indicate if changes were made. The Creative Commons Public Domain Dedication waiver (http://creativecommons.org/publicdomain/ zero/1.0/) applies to the data made available in this article, unless otherwise stated. 